\title{
Thermal impairment of reproduction is differentially expressed in maiden and repeat spawning Atlantic salmon
}

\author{
N.W.Pankhurst ${ }^{\mathrm{a}, *}$, H.R.King ${ }^{\mathrm{b}}$, K.Anderson ${ }^{\mathrm{c}}$, A. Elizur ${ }^{\mathrm{c}}$, P.M. Pankhurst ${ }^{\mathrm{a}}$, N.Ruff ${ }^{\mathrm{b}}$ \\ a Australian Rivers Institute, Griffith University, Gold Coast, Queensland 4222, \\ Australia \\ ${ }^{\mathrm{b}}$ Salmon Enterprises of Tasmania, P.O. Box 1, Wayatinah, Tas 7140, Australia \\ ${ }^{\mathrm{c}}$ Faculty of Science, Health and Education, University of the Sunshine Coast, Locked \\ Bag 4, Maroochydore DC, Qld 4558, Australia
}

\begin{abstract}
Groups of maiden or repeat spawning Atlantic salmon were maintained during vitellogenesis in austral autumn at either $14{ }^{\circ} \mathrm{C}$ or $22{ }^{\circ} \mathrm{C}$ through until April when all fish were transferred to a spawning temperature of $8{ }^{\circ} \mathrm{C}$. There was no difference in body weight within groups for maidens and repeats, with repeats being consistently larger than maidens, no difference in condition factor among groups, but consistently higher gonad weight in repeats than maidens. Gonadosomatic index (GSI) and follicle diameter were suppressed in both maidens and repeats at $22{ }^{\circ} \mathrm{C}$, with the effect being most marked in repeat spawners. Relative fecundity (egg $\mathrm{kg}^{-1}$ ) determined from ovarian tissue samples also showed depression in repeats at $22{ }^{\circ} \mathrm{C}$. Fish from both age classes held at $22{ }^{\circ} \mathrm{C}$ had a higher proportion of atretic follicles. Plasma levels of estradiol-17 $\beta\left(E_{2}\right)$ were strongly depressed in both maidens and repeats exposed to 22 ${ }^{\circ} \mathrm{C}$ throughout autumn but there was some evidence of recovery among maiden fish by late April. A similar effect was seen on plasma testosterone (T) levels. Plasma cortisol levels were generally low and typical of levels in unstressed fish indicating that stress did not account for the inhibitory effects observed Hepatic zona pellucida protein gene expression was significantly inhibited in both maiden and repeat spawning fish reared at $22{ }^{\circ} \mathrm{C}$, but with some evidence of recovery after temperature reduction to $8{ }^{\circ} \mathrm{C}$. Hepatic vitellogenin (Vtg) gene expression was also lower in both maiden and repeat spawning fish exposed to $22{ }^{\circ} \mathrm{C}$ and this was accompanied by reduced plasma Vtg levels in maidens, but not repeats at $22{ }^{\circ} \mathrm{C}$. Maidens at $14{ }^{\circ} \mathrm{C}$ began ovulating first followed by repeats at $14{ }^{\circ} \mathrm{C}$, then repeats at $22{ }^{\circ} \mathrm{C}$ followed by maidens at $22{ }^{\circ} \mathrm{C}$. There was reduced fertility in maidens at $22{ }^{\circ} \mathrm{C}$ relative to both maidens and repeats at $14{ }^{\circ} \mathrm{C}$, whereas repeats at $22{ }^{\circ} \mathrm{C}$ showed intermediate fertility between $14{ }^{\circ} \mathrm{C}$ fish and $22{ }^{\circ} \mathrm{C}$ maidens. Survival to the eyed egg stage was highest in maidens at $14{ }^{\circ} \mathrm{C}$, significantly suppressed at $22{ }^{\circ} \mathrm{C}$ in maidens, and at intermediate levels in repeats at both temperatures. This suggests that repeat spawning Atlantic salmon may be more robust in the face of thermal insult which combined with their larger size and egg production, could make their use desirable under production situations where there was any threat of exposure to higher than normal temperature.
\end{abstract}

Keywords: Atlantic salmon, temperature, reproduction, fertility, gonadal steroids, hepatic gene expression.

* Corresponding author. E-mail address: n.pankhurst@griffith.edu.au 


\section{Introduction}

It is increasingly clear that climate change will strongly affect aquatic poikilotherms including fish, and this will be variously expressed through changes in community composition and structure, changes in species range, local and perhaps widespread extinctions of some species (reviewed in Graham and Harrod, 2009). A reasonable expectation is that salmonids will be particularly susceptible due to their distributional preferences for cooler water (eg. Welch et al., 1998a,b; Reddin et al., 2000), and the fact that the complex anadromous life histories of many salmonid populations potentially expose them to thermal stress at a succession of critical life history stages (reviewed by Johnsson and Johnsson, 2009). Increases in temperature above optimal levels can have inhibitory effects on a range of biological processes including feeding and growth, behaviour, smoltification, disease resistance and reproduction (Battaglene et al., 2008; Steinum et al., 2008; Graham and Harrod, 2009; Johnson and Johnsson, 2009; Pankhurst and King, 2010). A point of particular sensitivity appears to be reproductive development in females whereby inappropriately elevated temperatures impair or retard ovarian steroidogenesis particularly $17 \beta$ - estradiol $\left(E_{2}\right)$ synthesis - and the subsequent hepatic synthesis of vitellogenin (Vtg), oocyte growth and development, oocyte maturation and ovulation, and egg fertility and survival (reviewed in Pankhurst and King, 2010).

Management strategies in culture situations are currently limited to thermal protection of broodstock during critical stages of vitellogenesis (Pankhurst and King, 2010); however, this requires significant infrastructure for thermal management and is not always possible in some aquaculture operations. A limited set of studies has examined the scope for endocrine therapy as a protectant during or after exposure to high temperature, mainly examining the value of treatment with synthetic analogues of gonadotropin releasing hormone (GnRHa). Treatment of an Australian cultured stock of Atlantic salmon (Salmo salar) with GnRHa was ineffective at maintaining fertility at high temperature but did restore fertility when applied in combination with a graded reduction in temperature (King and Pankhurst, 2004a). Similar experiments using longer release profile formulations of GnRHa in northern hemisphere stocks did result in maintenance of ovulation at elevated temperatures, but still with reduced egg survival at high temperatures (Vikingstad et al., 2008). The implication is that hormone therapy is only likely to be partially effective at offsetting the damaging effects of exposure to high temperature, although the more directs effects of gonadotropin or steroid therapy remain to be investigated (Pankhurst and King, 2010).

An unexplored area is the effect of thermal stress on different age classes of fish, with the majority of farmed salmon being from maiden or first-spawning broodstock The first cycle of reproduction in maiden spawning Atlantic salmon covers the initial period of reproductive maturation or puberty. Studies on other species suggest that puberty is associated with an increase in hypothalamic GnRH mRNA and this is followed by FSH expression and secretion and increased levels of steroid hormones (Okuzawa, 2002; Campbell et al., 2006). In addition, the recently discovered Gcoupled protein receptor GPR54 and its ligand the Kisspeptin have been shown to have an important role in initiating GnRH secretion (reviewed in Taranger et al., 2010). Blockades in the endocrine cascade prior to puberty have been identified at the levels of GnRH and FSH synthesis, and gonadotropin receptor binding at the gonadal level in a variety of species including salmonids (Gur et al., 2000; Okuzawa, 2002; Nocillado et al., 2007). The main effect of this appears to be the occurrence of a 'dummy run' with only partial endocrine activation and gonadal response, in the 
season before the first spawning period occurs, with the phenomenon being described in striped bass (Morone saxatilis) (Holland et al., 2000), masu salmon (Oncorhynchus masou) (Amano et al., 1992) and rainbow trout (Oncorhynchus mykiss) (Prat et al., 1996). In other species full 'endocrine maturity' may also not occur until the second spawning season. In both snapper (Pagrus auratus) (Cleary et al., 2000) and striped bass (Holland et al., 2000) relative ovarian size and plasma levels of gonadal steroids are lower in the first than the second spawning seasons. Cultured Atlantic salmon stocks in Tasmania are farmed towards the upper limit of their thermal tolerance range with the result that growth occurs at a faster rate, and developmental milestones are reached at a younger age than in their northern hemisphere counterparts, with most fish maturing as grilse after a single winter at sea (at 3 years of age) compared with 2 sea-winters in the northern hemisphere (King and Pankhurst, 2003). Rapidly maturing southern hemisphere Atlantic salmon do not appear to display the dummy run phenomenon. However, part of the inhibitory effect of elevated temperature could arise from its effect on grilse showing endocrine immaturity of the type described above for snapper and striped bass.

A key step in the maturation process is the production of $E_{2}$ by the developing ovarian follicle. $E_{2}$ is transported in the bloodstream to the liver where it binds to estrogen receptors (ER) in the hepatocyte cytoplasm. The $E_{2}$-ER complex in turn acts as a promoter for expression of the gene or genes coding for Vtg (reviewed in Watts et al., 2003), which is then sequestered into the developing oocyte through a process of receptor-mediated endocytosis (Tyler et al., 2000). The second important effect of $\mathrm{E}_{2}$ is to stimulate hepatic synthesis of precursors of three structural proteins (collectively termed ZP) that will form the zona pellucida of the developing oocyte, and subsequently the chorion of the mature egg (Tyler et al., 2000). The genes coding for $\mathrm{ZP}$ are highly sensitive to stimulation by $\mathrm{E}_{2}$ and $\mathrm{ZP}$ appear rapidly in the plasma soon after hepatic exposure to estrogens (Celius et al., 2000; Berg et al., 2004; Fujita et al., 2004). Disruption of $E_{2}$ synthesis and subsequent $E_{2}$-ER binding in the Tasmanian stock of Atlantic salmon is accompanied by chorionic abnormality, poor fertility and reduced embryonic survival (Pankhurst and King, 2010), suggesting that part of the effect may result from disruption of the expression of important $\mathrm{E}_{2}$ inducible genes.

The present study examined whether the effect of thermal insult is differentially expressed in different age classes of Atlantic salmon. Maiden (3 year old) and repeat (4 year old) spawners were exposed to temperatures previously shown to inhibit reproductive development in this stock, and effects on ovarian growth and plasma levels of gonadal steroids and hepatic synthesis of Vtg were assessed. In addition, the $\mathrm{E}_{2}$ - dependent expression of genes coding for Vtg and zona pellucida (ZP) proteins was also measured.

\section{Materials and methods}

\subsection{Fish Husbandry and Maintenance}

Maiden (first spawning 2+ year old fish) and repeat (second spawning 3+ year old fish) cultured adult females were held at the SALTAS Wayatinah Hatchery (Tasmania, Australia) at ambient temperature and photoperiod in either 200 (maidens) or 50 (repeats) $\mathrm{m}^{3}$ circular tanks at stocking densities of $12-18$, and $24-36 \mathrm{~kg} \mathrm{~m}^{-3}$ for maidens and repeats, respectively until early January 2008. In January, fish were divided into treatment groups ( $\mathrm{n}=28$ per group) and transferred to temperature- 
controlled $4 \mathrm{~m}^{3}$ tanks (14 fish per tank) under simulated ambient photoperiod. Fish were not fed from the time of transfer to the temperature controlled systems in January consistent with hatchery practice for management of this experimental stock of fish.

Treatment Groups

1. Maidens held at $14{ }^{\circ} \mathrm{C}$;

2. Repeats held at $14^{\circ} \mathrm{C}$;

3. Maidens held at $22{ }^{\circ} \mathrm{C}$;

4. Repeats held at $22{ }^{\circ} \mathrm{C}$.

All fish were maintained at the nominated temperature $\left(14\right.$ or $\left.22{ }^{\circ} \mathrm{C}\right)$ until early April when all fish were exposed to a temperature ramp down over 11 days to $8{ }^{\circ} \mathrm{C}$ to induce final oocyte maturation and ovulation (King and Pankhurst, 2000). Temperature profiles for the two temperature regimes are shown in Fig. 1.

\subsection{Sampling Protocol}

Fish from both maiden and repeat groups were sampled on the $31^{\text {st }}$ August and $2^{\text {nd }}$ November 2007, and $7^{\text {th }}$ January 2008 to cover the initiation of vitellogenesis for each age class (Samples 1 to 3), and after introduction to the controlled temperature regimes on the 14th February 2008 (Sample 4), $28^{\text {th }}$ March (Sample 5) and $25^{\text {th }}$ April (Sample 6). Seven fish were sampled from each group at each sample time, leaving 7 fish from each treatment to proceed through to ovulation and stripping, after the final destructive sample in April.

For sampling, fish were netted from the holding tanks, terminally anaesthetised in Aqi-S TM (Crop \& Food, New Zealand), weighed, measured and then blood sampled by caudal puncture using pre-heparinised syringes fitted with $22 \mathrm{G}$ needles. Blood plasma was centrifuged at $12000 \mathrm{~g}$ for 3 mins, and stored frozen at $-20{ }^{\circ} \mathrm{C}$ for later measurement of plasma hormones. Ovaries were excised, weighed and portions allocated to $50 \mathrm{~mL}$-pots containing teleost saline or $10 \%$ neutral buffered formalin for fecundity estimation and follicle measurement, and histology, respectively. Segments of liver were transferred to 1-2 mL of RNA Later TM (Qiagen, Germany) to stabilise mRNA for later measurement of gene expression. Samples were held overnight at 4 ${ }^{\circ} \mathrm{C}$, then stored at $-20{ }^{\circ} \mathrm{C}$.

Gonadosomatic indices (GSI) were calculated as (gonad weight/total body weight) $\mathrm{x} 100$, and condition factor (CF) as (body weight/length ${ }^{3}$ ) $\mathrm{x} 100$. Fecundity was determined by dispersing all ovarian follicles from an ovarian segment of $\sim 5 \mathrm{~g}$ in teleost saline using $22 \mathrm{G}$ needles, and counting all vitellogenic (opaque) follicles present in the sample. Total fecundity was determined by correction for total ovarian weight and expressed as relative fecundity $\mathrm{kg}^{-1}$ body weight. Follicle size distributions were determined by measuring the horizontal diameter of 50 follicles from each fish, using an eye piece micrometer fitted to a dissecting microscope. Fixed tissue for histology was dehydrated in an ethanol series, embedded in paraffin wax, sectioned at $5 \mu \mathrm{m}$ and stained with hematoxylin and eosin. At ovulation, ova were stripped and fertilised as described in King et al. (2003) for measurement of egg size, fertility and survival to the eyed stage at 250 degree-days of incubation. All animal experiments were conducted in accordance with Australian law under ethical approval EAS/02/07/AEC issued by the Griffith University Animal Ethics Committee.

\subsection{Plasma Steroid and Vitellogenin Measurement}


Plasma levels of $E_{2}$, testosterone $(T)$ and cortisol were measured by radioimmunoassay in $100 \mu \mathrm{L}$ plasma extracted with $1 \mathrm{~mL}$ ethyl acetate using the protocol and reagents for $E_{2}$ and $T$ as described in Pankhurst and Carragher (1992), and for cortisol as in Pankhurst et al. (2008). Extraction efficiency was determined by recovery of ${ }^{3} \mathrm{H}$-labelled steroid from replicates of a plasma pool and was 78, 79 and $74 \%$ for $E_{2}$, T, and cortisol, respectively. Assay values were corrected accordingly for extraction losses. Interassay variability was determined by repeat measurement of a pooled internal standard and was (\% CV) 7.4, 13.9 and $12.3(\mathrm{n}=2)$, for $\mathrm{E}_{2}, \mathrm{~T}$ and cortisol, respectively.

Plasma Vtg levels were measured by enzyme linked immunosorbent assay using the reagents and protocol described in Watts et al. (2003). Plasma samples were diluted at 1:1000 in assay buffer for measurement. Interassay was assessed by repeat measurement of a Vtg standard from the central part of the assay curve and was (\% CV) $13.1(n=6)$. Pooled internal standards were not used here due to the tendency of Vtg to denature following repeated freeze-thaw cycles.

\subsection{Measurement of hepatic gene expression}

\section{RNA isolation and cDNA synthesis}

Total RNA was isolated from hepatic tissue using the Illustra RNAspin Mini kit (GE Healthcare, United Kingdom) according to the manufacturer's protocol. Four hundred nanograms of liver-derived RNA were used to synthesize cDNA for use in polymerase chain reactions (PCRs), and real-time/quantitative PCR (qPCR) using the QuantiTect ${ }^{\circledR}$ reverse transcription kit (Qiagen, Germany). This kit includes a DNA elimination step to remove potential contamination of PCRs by genomic DNA. Following synthesis, cDNAs were diluted 5-fold with diethylprocarbonate (DEPC)treated water and stored at $-20^{\circ} \mathrm{C}$ until use.

Partial isolation of ZPC gene

To amplify a fragment of the zona pellucida $\mathrm{C}$ (ZPC, equivalent to ZP3, ZP $\gamma$ and choriogenin $\mathrm{L}$ ) gene from $S$. salar, the ZPC mRNA nucleotide sequences from rainbow trout (GenBank accession number AF231708), masou salmon (Oncorhynchus masou) (EU042126) and Java medaka (Oryzias javanicus) (AY913760) were aligned using the ClustalW2 sequence alignment tool (http://www.ebi.ac.uk/) and degenerate primers were designed from conserved regions (ZPC F1 and ZPCR1, Table 1). The $25 \mu \mathrm{L}$ PCR reaction contained $17.9 \mu \mathrm{L}$ PCR grade water, $2.5 \mu \mathrm{L}$ 10x PCR buffer, $0.5 \mu \mathrm{L} 10 \mathrm{mM}$ dNTPs, $2 \mu \mathrm{L} 25 \mathrm{mM} \mathrm{MgCl}$, 500 $\mathrm{nM}$ forward primer, $500 \mathrm{nM}$ reverse primer, $0.1 \mu \mathrm{L}$ TAQ (Fisher Biotec, Australia) and $1 \mu \mathrm{L}$ liver derived cDNA template. Thermal cycling consisted of an initial denaturation step at $94{ }^{\circ} \mathrm{C}$ for $1 \mathrm{~min}$; followed by 34 cycles of $94{ }^{\circ} \mathrm{C}$ for $30 \mathrm{~s}, 49{ }^{\circ} \mathrm{C}$ for $30 \mathrm{~s}$ and $72{ }^{\circ} \mathrm{C}$ for $4 \mathrm{~min}$; with a final $10 \mathrm{~min}$ incubation at $72{ }^{\circ} \mathrm{C}$. The PCR product was purified using the QIAquick ${ }^{\circledR}$ PCR purification kit (Qiagen) and cloned using the $\mathrm{pGEM}^{\circledR}-\mathrm{T}$ easy vector system (Promega, Madison, WI) according to the manufacturer's instructions. Clones were selected via blue/white screening and successful transformation was confirmed via colony PCRs using M13 primers designed by Promega. PCRs which yielded a product of the expected size were purified (as above) then sequenced by the Australian Genome Research Facility before being submitted to GenBank (accession number GU075906).

qPCR primer design

Gene specific primers (GSPs) for vitellogenin A (Vtg), zona pellucida B (ZPB, designed to detect all known ZPB genes), ZPC, and the potential qPCR reference 
genes: hypoxanthine phosphoribosyltransferase 1 (HPRT1), TATA box binding protein (TBP), elongation factor 1 alpha $(\mathrm{EF} 1 \alpha)$ and beta tubulin ( $\beta$-tubulin) were designed from species-specific mRNA sequences using Primer3 software (http://frodo.wi.mit.edu/primer3/, Table 2). All primers were designed to have an optimum annealing temperature of $60{ }^{\circ} \mathrm{C}$ and were supplied by GeneWorks (Australia). qPCR validations

qPCRs were conducted on a Rotor-gene 6000 series thermal cycler (Qiagen) using Platinum ${ }^{\circledR}$ SYBR $^{\circledR}$ Green qPCR SuperMix-UDG (Invitrogen) as the fluorescent label according to the manufacturer's instructions. Validation curves were carried out in triplicate using serially diluted cDNA as the template and the following cycling conditions: $50^{\circ} \mathrm{C}$ for $2 \mathrm{~min}$; $95^{\circ} \mathrm{C}$ for $2 \mathrm{~min}$; 40 cycles of $95^{\circ} \mathrm{C}$ for $15 \mathrm{~s} ; 60^{\circ} \mathrm{C}$ for 15 $\mathrm{s}$, and $72{ }^{\circ} \mathrm{C}$ for $20 \mathrm{~s}$ (acquiring). At the end of cycle 40, all primers were tested for specificity via melt curve analysis which consisted of a $90 \mathrm{~s}$ preconditioning step at 72 ${ }^{\circ} \mathrm{C}$, followed by a temperature gradient up to $95{ }^{\circ} \mathrm{C}$ at $1{ }^{\circ} \mathrm{C}$ per $5 \mathrm{~s}$. Following amplification, the size of all qPCR products was determined by running $4 \mu \mathrm{L}$ of the product on a $2 \%$ agarose gel; gene identity was then confirmed through sequencing. In each qPCR run, negative reverse transcription and no-template controls were analysed to ensure the absence of genomic DNA and other contamination. Reaction efficiencies (Table II) were automatically calculated by Rotor-gene software version 1.7.87 using the equation: $E=\left[10^{(-1 / M)}\right]-1$, where $E$ is equal to efficiency and $M$ is equal to slope.

qPCR protocol

To determine the relative expression of target genes, the $10 \mu \mathrm{L}$ qPCR reaction contained $5 \mu \mathrm{L}$ SYBR, $200 \mathrm{nM}$ forward primer, $200 \mathrm{nM}$ reverse primer, $1.6 \mu \mathrm{L}$ PCR grade water and $3 \mu \mathrm{L}$ of diluted cDNA template. Cycling parameters and melt curve analysis were as described above. In each qPCR run and for every gene analysed, negative no-template controls and a calibrator sample were included to detect possible contamination, and control for in-between run variability, respectively. The reference gene selected for expression normalisation was TBP as it showed consistently high stability under the experimental conditions, and did not change across time or developmental stage. The software REST ${ }^{\complement}$ 2008, V2.0.7 (Pfaffl et al., 2002) was used to calculate expression of key genes relative to TBP expression for each sample.

\subsection{Statistical analysis}

Pairwise comparison of means of morphometric and plasma hormone data (Samples 1 to 3) was made using an independent samples t-test, and multiple comparisons (subsequent sample times) using one-way ANOVA with comparison of means by Tukeys-b using the SPSS (version 17.0) statistical package. Differences in relative gene expression levels were detected non-parametrically using the KruskalWallis test coupled with Bonferroni's Correction to reduce the risk of type 1 error. The $\mathrm{P}$ value for significance was set at 0.05 for all analyses.

\section{Results}

There was no difference in body weight within groups for maidens and repeats, with repeats being consistently larger than maidens (maidens $2.2-4 \mathrm{~kg}$, repeats $4-9 \mathrm{~kg}$ over the sampling period; data not shown). Condition factor was lower in the repeats than the maidens at Samples 1 and 2 but these fish had recovered by Sample 3 and 
there was no difference in CF thereafter (data not shown). Gonad size as measured by GSI was low in both age classes at Samples 1 and 2 (and higher in repeats than maidens at Sample 1 only), then increased rapidly from Sample 3 onwards (Fig. 2). GSI was depressed in maidens at $22{ }^{\circ} \mathrm{C}$ with respect to repeats at both temperatures at Sample 4, not different among groups at Sample 5 and depressed in both age classes at $22{ }^{\circ} \mathrm{C}$ relative to repeats at $14{ }^{\circ} \mathrm{C}$ at Sample 6 (Fig. 2). The mean diameter of vitellogenic follicles was around $1 \mathrm{~mm}$ in both age classes at Samples 1 and 2 but increased rapidly in concert with gonad size, from Sample 3 onwards. Follicle diameters were not different between age classes for the first three samples, larger in repeats than maidens at both temperatures at Sample 4, smaller in both age classes at $22{ }^{\circ} \mathrm{C}$ than their respective $14{ }^{\circ} \mathrm{C}$ counterparts at Sample 5, and lower in all groups relative to $14{ }^{\circ} \mathrm{C}$ repeats at Sample 6 (Fig. 2). Representative follicle size distributions (chosen from fish where the modal follicle size class was close to the group mean for that sample time) showed a progression of modal size with time that mirrored increases in mean follicle diameter (Fig. 3). There was a high level of size synchrony in both maidens and repeats at Samples 1 and 2, but this disappeared in January when there was a wide spread of size classes present in association with recruitment of follicles into the major growth phase of vitellogenesis. This trend was maintained in repeats at Sample 4 in February. Thereafter, both groups showed increasing size synchrony as follicle size increased. There are no obvious effects of exposure to $22{ }^{\circ} \mathrm{C}$ on follicle size distribution, with the pattern of development being very similar in all groups (Fig. 3). Absolute fecundity was higher in repeats at all times except in fish held at $22{ }^{\circ} \mathrm{C}$ at Sample 6 (Fig. 4). Relative fecundity (eggs $\mathrm{kg}^{-1}$ ) was variable but again showed depression in repeats at $22^{\circ} \mathrm{C}$ by Sample 6 (Fig. 4).

Histological assessment of ovarian condition showed a gradual transition in gonadal stage in both maiden and repeat spawners from gonads which had a mixture of small pre-vitellogenic and early-stage vitellogenic follicles at Sample 1, to ovaries in which larger vitellogenic follicles predominated by Sample 3. Ovaries of maidens and repeats were structurally similar but with the exception that the gonads of repeats retained remnants of atretic vitellogenic mature follicles that had not ovulated in the previous spawning season (Table 3). Generally, only the thick, highly refractile egg membrane (zona pellucida) of these atretic follicles remained. No atretic follicles were observed in the ovaries of maiden fish. By Sample 4, ovaries of repeat and maiden spawning fish from both temperature treatments were characterised by the predominance of large vitellogenic follicles, with atretic previous-season follicles (based on zona pellucida thickness) still present in the ovaries of some repeat spawners. At Sample 5, irrespective of thermal regime, gonadal tissue was characterised by enlargement of vitellogenic follicles, consistent with changes in follicle size-class distribution reported above. The ovaries of fish from both $14{ }^{\circ} \mathrm{C}$ and $22{ }^{\circ} \mathrm{C}$ treatments showed atresia within the current season's follicles. At $14{ }^{\circ} \mathrm{C}, 2$ out of 7 fish in both maiden and repeat groups had atretic follicles, but the prevalence of these within the sample of tissue sectioned was low (usually 1-2 follicles). In contrast, 3 out of 7 of the maidens, and 5 out of 7 of the repeats held at $22{ }^{\circ} \mathrm{C}$ showed follicular atresia, and the prevalence of atresia was high, with multiple follicles within the sample tissue affected (Table 3). The pattern was maintained at Sample 6.

Ovulations were complete in all groups at approximately the same time; however, maidens at $14{ }^{\circ} \mathrm{C}$ began ovulating first followed by repeats at $14{ }^{\circ} \mathrm{C}$, then repeats at 22 ${ }^{\circ} \mathrm{C}$ followed by maidens at $22{ }^{\circ} \mathrm{C}$ (Fig. 5). There were no statistical differences in postovulatory fecundity among groups, although repeats tended to have higher egg production than maidens (Fig. 6). Relative fecundity was also not different between 
groups. Egg diameter and volume were both larger in repeats than maidens at $14{ }^{\circ} \mathrm{C}$, however, this difference disappeared in repeats exposed to $22{ }^{\circ} \mathrm{C}$. There was markedly reduced fertility in maidens at $22{ }^{\circ} \mathrm{C}$ relative to both maidens and repeats at $14{ }^{\circ} \mathrm{C}$ (Fig. 7). Repeats at $22{ }^{\circ} \mathrm{C}$ showed intermediate fertility between $14{ }^{\circ} \mathrm{C}$ repeats and 22 ${ }^{\circ} \mathrm{C}$ maidens. Survival to the eyed egg stage was highest in maidens at $14{ }^{\circ} \mathrm{C}$, significantly suppressed at $22{ }^{\circ} \mathrm{C}$ in maidens, and at intermediate levels in repeats at both temperatures (Fig. 6).

Plasma levels of $E_{2}$ were higher in maidens than repeats at Samples 1 and 2, but not different at sample 3 (Fig. 7). At Samples 4 and 5, $\mathrm{E}_{2}$ levels in both maidens and repeats were suppressed at $22{ }^{\circ} \mathrm{C}$ relative to $14{ }^{\circ} \mathrm{C}$, but by Sample 6, only repeats showed lower $\mathrm{E}_{2}$ levels at $22{ }^{\circ} \mathrm{C}$ than $14{ }^{\circ} \mathrm{C}$. Plasma $\mathrm{T}$ levels were not different at Samples 1 and 2 but higher in repeats at Sample 3. At Sample 4, plasma T levels in repeats were lower at 22 than at $14{ }^{\circ} \mathrm{C}$, and at Sample 5 plasma $\mathrm{T}$ levels were lower in both maidens and repeats at 22 than at $14{ }^{\circ} \mathrm{C}$ (Fig. 7). By Sample 6, T levels were lower in maidens at $22{ }^{\circ} \mathrm{C}$ than at $14{ }^{\circ} \mathrm{C}$ but there was no difference between temperatures in repeats. Plasma cortisol levels were elevated in maiden fish relative to repeats at Samples 1-3 (means of up to $20 \mathrm{ng} \mathrm{mL}^{-1}$ compared with $<5 \mathrm{ng} \mathrm{mL}^{-1}$ in repeats; data not shown). This was thought to relate to the crowding process required to catch maidens from the larger volume $200 \mathrm{~m}^{3}$ tanks. At Samples 4-6, plasma cortisol levels were below $10 \mathrm{ng} \mathrm{mL}^{-1}$ in all groups and there was no effect of holding temperature (data not shown).

Plasma Vtg levels were elevated in maidens compared with repeats at the first 3 sampling times (Fig. 8). This pattern was still present at Sample 4, and maidens but not repeats at $22{ }^{\circ} \mathrm{C}$ showed suppression relative to the $14{ }^{\circ} \mathrm{C}$ treatment. There were no differences among treatments at sample 5, but plasma Vtg levels of repeats at 22 ${ }^{\circ} \mathrm{C}$ were elevated over those of repeats at $14{ }^{\circ} \mathrm{C}$ at Sample 6 (Fig. 8). Relative levels of hepatic Vtg gene expression were low in both maidens and repeats at Samples 1 and 2, but increased markedly at Sample 3, with levels being higher in maidens than in repeats (Fig. 8). There was no difference between groups at Sample 4, but expression was suppressed at $22{ }^{\circ} \mathrm{C}$ in both maidens and repeats at Sample 5. At Sample 6, expression was suppressed in maidens, but not repeats at $22{ }^{\circ} \mathrm{C}$, relative to fish at 14 ${ }^{\circ} \mathrm{C}$ (Fig. 8).

ZPB gene expression was low in both age classes at Samples 1 and 2, but higher in maidens than repeats at sample 1 (Fig. 9). As with Vtg expression, there was a large increase at Sample 3, with maidens again showing higher expression than repeats. At Samples 4-6, ZPB gene expression was suppressed in both maidens and repeats at 22, relative to $14{ }^{\circ} \mathrm{C}$. ZPC gene expression followed a similar pattern with low levels of expression at samples 1 and 2 and an increase at sample 3, but here with no differences between maidens and repeats. At Sample 4, expression was not different among groups, whereas at Samples 5 and 6, there was suppression of expression at 22 relative to $14{ }^{\circ} \mathrm{C}$ in repeats but not maidens (Fig. 9).

\section{Discussion}

Developmental trajectories of maiden Atlantic salmon held at $14{ }^{\circ} \mathrm{C}$ in the present study were similar to those previously described for this population (King and Pankhurst, 2003), with vitellogenesis occurring in late austral spring and accelerating through summer and autumn, prior to the peak of ovulation in late May and early June. The temporal pattern of repeat spawners held at $14{ }^{\circ} \mathrm{C}$ was very similar to that of 
maidens, with the minor difference that repeats initially had lower somatic condition factors than maidens, reflecting recovery from the energetic demands of the previous spawning season. This difference had disappeared by January. Both age classes showed similar patterns of oocyte size distribution, with a period of relatively unsynchronised growth of the oocyte clutch in January and February. At later sample times this resolved into much tighter size distribution of the maturing oocyte clutch. A similar pattern of oocyte growth has been previously described for this population (King and Pankhurst, 2003), and also for rainbow trout (Tyler et al., 1990).

Despite very similar developmental trajectories, repeat spawners in the present study were slightly slower to ovulate, with equivalent levels of cumulative ovulation being reached about a week later in repeats than in maidens. Plasma profiles of $\mathrm{T}$ and $\mathrm{E}_{2}$ were generally similar in maidens and repeats at $14{ }^{\circ} \mathrm{C}$, and consistent with previously described steroid profiles for this stock (King and Pankhurst, 2003; King et al., 2003). However, plasma $E_{2}$ levels were lower in repeats than maidens during the initial stages of ovarian development (August and November), and this was accompanied by lower plasma Vtg levels and at some sample times Vtg and ZPB gene expression during the spring and early summer. This suggests that despite the similar follicle growth trajectories, increases in $\mathrm{E}_{2}$ synthesis and the $\mathrm{E}_{2}$-dependent hepatic expression of Vtg and ZP genes are delayed in repeats relative to maidens, and that the slightly slower progression to ovulation is a reflection of this. The pattern appears not be universal among salmonids with maiden and repeat spawning rainbow trout showing very similar temporal patterns of increase in plasma levels of $T$ and $E_{2}$. Maiden spawners did; however, show a biphasic spring increase in plasma Vtg that was absent in repeats (Scott and Sumpter, 1983; Sumpter et al., 1984).

Exposure of Atlantic salmon broodstock in the present study to $22{ }^{\circ} \mathrm{C}$ had no detectable impact on fish size or condition, but did result in suppression of relative gonad size and follicle diameter in repeats but not maidens. Exposure to high temperature did not noticeably affect follicle size distribution or fecundity, suggesting that the dynamics of oocyte recruitment were unaffected at higher temperature. Oogenesis and recruitment of follicles into vitellogenesis in salmonids and other species are closely associated with increases with expression of follicle stimulating hormone (FSH), its ovarian receptor (FSH-R), and plasma $\mathrm{E}_{2}$ levels (Campbell et al., 2006; Lubzens et al., 2010). Both $\mathrm{E}_{2}$ synthesis and FSH and FSH-R expression have been demonstrated to be suppressed by exposure to elevated temperatures (Soria et al., 2008; Pankhurst and King, 2010); however, the critical period for this process appears to be early in development, and in the present study this would have occurred during austral spring before the imposition of thermal challenge, suggesting that oocyte recruitment is relatively robust once it is established.

Maintenance at $22{ }^{\circ} \mathrm{C}$ in the present study did generate a higher incidence of ovarian atresia in both age classes, and progress to ovulation was also retarded with the effects being most marked in maidens. This was accompanied by significant reductions in egg fertility and survival in maiden fish but not repeats. The inhibitory effects of exposure to elevated temperature on follicle size, ovulation and egg fertility and survival are consistent with earlier studies on this stock (King and Pankhurst 2000; 2004a,b; King et al., 2003; 2007; Watts et al., 2004;), and also northern hemisphere populations of Atlantic salmon (Taranger and Hansen, 1993; Taranger et al., 2003; Vikingstad et al., 2008), Arctic charr (Salvelinus alpinus) (Gillet, 1991), brook trout (S. fontinalis) (Hokanson et al., 1973), and southern hemisphere stocks of rainbow trout (Pankhurst et al., 1996; Pankhurst and Thomas, 1998). The present study is the first to present evidence that the age class of the reproductive stock can 
influence the response to thermal challenge, and in particular, that repeat spawners may be more robust in terms of their reproductive response to exposure to high temperature, despite the fact that inhibition of follicle growth and related endocrine processes (see following discussion) still occurs.

Consistent with earlier studies (reviewed in Pankhurst and King, 2010), plasma levels of $E_{2}$ were depressed in the present study in both age classes of fish held at 22 ${ }^{\circ} \mathrm{C}$, in February and March, and also among repeats in April. This supports the view that a key effect of exposure to higher than normal temperature is inhibition of $\mathrm{P}_{450}$ aromatase (arom) activity, with subsequent reductions in $\mathrm{E}_{2}$ synthesis and release to the plasma (Watts et al., 2004). There is increasing evidence that thermal inhibition of arom activity occurs across a taxonomically diverse range of teleosts (Guiguen et al., 2010). However, plasma $T$ levels were also suppressed in fish of both age classes held at $22{ }^{\circ} \mathrm{C}$ in the present study, and this effect has also been observed previously in this stock of Atlantic salmon (King et al., 2003; 2007). This indicates that processes higher in the endocrine pathway were also affected by exposure to elevated temperature. In vitro studies have shown that ovarian steroidogenesis upstream of $\mathrm{E}_{2}$ production is strongly maintained in the face of thermal challenge (Watts et al., 2004), suggesting that effects on plasma $\mathrm{T}$ levels were generated higher in the endocrine cascade than at the level of gonadal steroidogenesis. Candidates include the transcription and synthesis of gonadotropin releasing hormone and its pituitary receptor, and luteinising $\beta$-subunit (LH- $\beta$ ) (Okuzawa et al., 2003; Soria et al., 2008).

Plasma cortisol measurements in the present study suggested that suppression of plasma $\mathrm{T}$ and $\mathrm{E}_{2}$ levels were not the result of stress suppression of gonadal steroidogenesis of the type described for a wide range of teleosts (reviewed by Schreck, 2010). Plasma cortisol was only elevated above levels typical of unstressed adult fish from this stock (Thomas et al., 1999), in maiden fish sampled with crowding from a large stock tank, early in the experiment. At all other times, cortisol levels were low, and not different between treatments or age classes, indicating that the experimental conditions themselves were not perceived as stressful.

Hepatic Vtg gene expression and subsequent synthesis is strongly $\mathrm{E}_{2}$-dependent (reviewed by Babin et al., 2007), and this is reflected in the present study by the increase in Vtg expression through samples 1-3 concomitant with increasing plasma $\mathrm{E}_{2}$ concentrations. However, there was not a consistent subsequent relationship between $E_{2}$ and Vtg expression, with suppression in plasma $E_{2}$ at $22{ }^{\circ} \mathrm{C}$ in February and March, but reduced Vtg gene expression in March only. This suggests that either there is a time lag between reductions of plasma $E_{2}$ and subsequent effects on Vtg expression, or that beyond a certain level of stimulation, plasma $E_{2}$ levels and $E_{2}-$ dependent gene activation become to an extent, uncoupled. The relatively short latency between increases in plasma $\mathrm{E}_{2}$ and Vtg production (Sun et al., 2003), and the occurrence of weak relationships between absolute levels of $E_{2}$ and Vtg or ovarian growth in a number of species (reviewed in Pankhurst, 2008) suggest that the second explanation is more likely.

A similar effect was observed in plasma Vtg levels where despite reductions in both plasma $\mathrm{E}_{2}$ and Vtg gene transcription, only maidens held at $22{ }^{\circ} \mathrm{C}$ showed significant suppression of plasma Vtg levels, and only at the February sample. Suppression of plasma Vtg levels at higher temperatures has previously been described for maidens of this stock (King et al., 2003; Watts et al., 2004) but also with the most marked effects occurring during February and March. A subsequent study confirmed that the most thermally sensitive period was February-March where maintenance at $22{ }^{\circ} \mathrm{C}$ for discrete 28 day periods suppressed plasma Vtg (King et al., 2007). In all three studies 
there was some recovery in plasma Vtg levels among fish held at high temperature by April, and the same effect was found in the present study.

ZPB and ZPC gene expression showed similar patterns of increase with ovarian growth and development as plasma $E_{2}$ and Vtg with maidens again showing earlier increases than repeats. The suppression of ZPB gene expression in both age classes at $22{ }^{\circ} \mathrm{C}$, and the suppression of ZPC gene expression among repeats is generally consistent with the role of $\mathrm{E}_{2}$ in stimulating both ZPB and ZPC gene expression (reviewed in Modig et al., 2007), with suppression of ZPB gene expression being correlated with reductions in plasma $\mathrm{E}_{2}$ in the present study. The effect on ZPC gene expression was less marked and this may relate to the fact that ZP expression can be modulated by other endocrine factors including cortisol and androgens (Modig et al., 2007).

Both age classes in the present study showed endocrine suppression in the face of extended exposure to maintenance at $22{ }^{\circ} \mathrm{C}$, but only maiden fish showed significant reductions in subsequent egg fertility and survival relative to $14{ }^{\circ} \mathrm{C}$ controls. Repeats showed some apparent reduction in fertility and survival, albeit not to levels that were significantly different from fish held at $14{ }^{\circ} \mathrm{C}$. There are multiple determinants of egg quality (reviewed in Lubzens et al., 2010); however, a notable difference between maidens and repeats in the present study appears to be the suppression of plasma Vtg levels in maidens only. Critically, this effect occurred in February, the time which our previous studies have identified as a period of high sensitivity to thermal insult (King et al., 2007). This period also coincides with the major period of oocyte growth and when the ovary shows the highest level of asynchrony of growth of the developing oocyte clutch (King and Pankhurst, 2003; this study). The genesis of the differential age class response is not clear, particularly given that both the age classes showed thermal suppression of plasma $E_{2}$, Vtg and ZPB gene expression, but may relate to the size of the broodstock fish. Repeats held at $14{ }^{\circ} \mathrm{C}$ generally had larger follicle diameters than maidens, and this may indicate that they have greater capacity to sequester resources into growing oocytes than younger (smaller) fish. This size effect may provide some protective advantage to repeats in terms of their capacity to recover from thermal stress. A study by Bromage et al. (1992) showed that egg size in rainbow trout was not a strong predictor of egg quality; however, more recent investigations in a range of salmonid species have confirmed the role of maternal investment in the determination of egg size, and that egg size tends to be positively correlated with subsequent larval survival (Pakkasmaa et al., 2001; Janhunen et al., 2010). This does not preclude the possibility that repeats are also more efficient at mobilising and sequestering other factors that enhance egg viability. Possible candidates here include vitamins $\mathrm{A}$ and $\mathrm{E}$, and low density lipoproteins accumulated independently of Vtg sequestration (reviewed in Lubzens et al., 2010).

A critical stage of egg formation involves the deposition and structural organisation of ZP proteins that will ultimately compose the egg chorion (Modig et al., 2007). In turn, integrity of the chorion is strongly implicated in egg viability in both Atlantic salmon (King et al., 2003) and chinook salmon (Oncorhynchus tshawytscha) (Barnes et al., 2003). There were no differences between age classes in ZPB gene expression in thermally challenged fish in the present study, and ZPC gene expression was reduced only in repeats where there was not significant suppression of fertility or survival. Acknowledging that gene transcription, and subsequent protein synthesis and chorion assembly are not synonymous, the results of the present study do suggest that the basis for age class differences identified here may not reside in differences in chorion assembly and integrity. 
The most effective way to protect Atlantic salmon broodstock from thermal insult remains the isolation of fish from temperature change during the critical early autumn period of vitellogenesis (Pankhurst and King, 2010). The results of the present study suggest that in the absence of the capacity to do this, the use of repeat spawning stock may partially offset the effects of exposure to elevated temperature. This may offer a management alternative for culture situations where large-scale temperature control is not a practical option. The phenomenon described here may also have some implications for egg survival among natural stocks exposed to elevated temperatures during vitellogenesis. Natural spawning runs of Atlantic salmon contain variable numbers of repeat spawners, accounting for example, in UK rivers, from $<1-34 \%$ of spawning fish (Phillips and Rix, 1988). Increased egg survival from these fish at a similar level over maidens under conditions of thermal stress to that seen in the present study means that repeat spawners could contribute disproportionately to egg survival. For example, in a spawning run containing $34 \%$ repeat spawners, egg survival and fecundity data from the present study (fecundity is on average 1.25 times higher in repeats than in maidens, egg survival for repeats at $22^{\circ} \mathrm{C}$ is 1.2 times that of maidens) might predict that the viable egg contribution from repeat spawners could be as high as $43 \%$ of the total. However, capture data from Scottish coastal net fisheries monitored since the mid 1960s shows that the capture of repeat spawners entering Scottish waters is generally much lower (1\% or less) (Julian Maclean, Marine Scotland Science, pers.comm.) suggesting that any impacts would be more modest. The present study does further emphasize the complexity of quantifying the effects of climate change on reproduction in natural stocks of fish.

\section{Acknowledgements}

This study was funded by the Australian Government through the Fisheries Research and Development Corporation, Salmon Enterprises of Tasmania Pty Ltd (Saltas), and Griffith University and University of the Sunshine Coast Research Encouragement Grants. Thanks are also extended to Saltas for extensive in kind support for the project.

\section{References}

Amano, M., Aida, K., Okumoto, N., Hasegawa, Y. 1992. Changes in salmon GnRH and chicken GnRH-II contents in the brain and pituitary, and GTH contents in the pituitary in female masu salmon, Oncorhynchus masou, from hatching through ovulation. Zool. Sci. 9, 375-386.

Babin, P.J., Carnevali, O., Lubzens, E., Schneider, W.J. 2007. Molecular aspects of oocyte vitellogeneisis in fish. In: Babin, P.J., Cerdá, J., Lubzens, E. (Eds.), The Fish Oocyte: From Basic Studies to Biotechnical Applications. Springer, Dordrecht, pp. 39-76.

Barnes, M.E., Cordes, R.J., Sayler, W.A., Hanten, R.P. 2003. Soft-egg disease in landlocked fall chinook salmon eggs: Possible causes and therapeutic treatments. Nth. Amer. J. Aquacult. 65, 126-133.

Battaglene, S., Carter, C., Hobday, A.J., Lyne, V., Nowak, B. 2008. Scoping study into adaptation of the Tasmanian salmonid aquaculture industry to potential impacts of climate change. National Agriculture and Climate Change Action 
Plan: Implementation Programme Report. Hobart: Tasmanian Aquaculture and

Fisheries Institute. Available at www.tafi.org.au/index.php/site/publications/

Berg, A.H., L.Westerlund, P.E.Olsson. 2004. Regulation of Arctic char (Salvelinus alpinus) egg shell proteins and vitellogenin during reproduction and in response to 17 $\beta$-estradiol and cortisol. Gen. Comp. Endocrinol. 135, 276-285.

Bromage, N., Jones, J., Randall, C., Thrush, M., Davies, B., Springate, J.R.C., Duston, J., Barker, G. 1992. Broodstock management, fecundity, egg quality and the timing of egg production in the rainbow trout (Oncorhynchus mykiss). Aquaculture 100, 141-166.

Campbell, B., Dickey, J., Beckman, B., Young, G., Pierce, A., Fukada, H.,Swanson, P. 2006. Previtellogenic oocyte growth in salmon: relationships among body growth, plasma insulin-like growth factor-1, estradiol-17 $\beta$, follicle stimulating hormone and expression of ovarian genes for insulin-like growth factors, steroid-acute regulatory protein and receptors for gonadotropins, growth hormone, and somatolactin. Biol. Reprod. 75, 34-44.

Celius, T., Matthews, J.B., Giesy J.P., Zacharewski, T.R. 2000. Quantification of rainbow trout (Oncorhynchus mykiss) zona radiata and vitellogenin mRNA levels using real-time PCR after in vivo treatment with estradiol-17 $\beta$ or $\alpha$ zearalenol. J. Steroid Biochem. 75, 109-119.

Cleary, J.J., Pankhurst, N.W., Battaglene, S.C. 2000. The effect of capture and handling stress on plasma steroid levels and gonadal condition in wild and farmed snapper, Pagrus auratus (Sparidae). J. World Aquacult. Soc. 31, 558569.

Fujita, T., Fukada, H., Shimizu, M., Hiramatsu, N., Hara, A. 2004. Quantification of serum levels of precursors to vitelline envelope proteins (choriogenins) and vitellogenin in estrogen treated masu salmon Oncorhynchus masou. Gen. Comp. Endocrinol. 136, 49-57.

Gillet, C. 1991. Egg production in an Arctic charr (Salvelinus alpinus L.) brood stock: Effects of temperature on the timing of spawning and the quality of eggs. Aquat. Liv. Res. 4, 109-116.

Graham, C.T., Harrod, C. 2009. Implications of climate change for the fishes of the British Isles. J. Fish Biol. 74, 1143-1205.

Guiguen, Y., Fostier, A., Piferrer, F., Chang, C-F. 2010. Ovarian aromatase and estrogens: A pivotal role for gonadal sex differentiation and sex change in fish. Gen. Comp. Endocrinol. 165, 352-366.

Gur, G., Melamud, P., Gissis, A., Yaron, Z. 2000. Changes along the pituitarygonadal axis during maturation of the black carp, Mylopharyngodon piceus. J. Exp. Zool. 286, 405-413.

Hokanson, K.E.F., McCormick, J.H., Jones, B.R., Tucker, J.H. 1973. Thermal requirements for maturation, spawning, and embryo survival of the brook trout, Salvelinus fontinalis. J. Fish. Res. Bd. Canada. 30, 975-984.

Holland, M.C., Hassin, S., Zohar, Y. 2000. Gonadal development and plasma steroid levels during pubertal development in captive-reared striped bass, Morone saxatilis. J. Exp. Zool. 286, 49-63.

Janhunen, M., Piironen, J., Peuhkuri, N. 2010. Parental effects on embryonic viability and growth in Arctic charr Salvelinus alpinus at two incubation temperatures. J. Fish Biol. 76, 2558-2570. 
Jonsson, B., Jonsson, N. 2009. A review of the likely effects of climate change on anadromous Atlantic salmon Salmo salar and brown trout Salmo trutta with particular reference to water temperature and flow. J. Fish Biol. 75, 2381-2447.

King, H.R., Pankhurst, N.W. 2000. Ovulation of Tasmanian Atlantic salmon maintained at elevated temperatures: implications of climate change for sustainable industry development. In Norberg, B., Kjesbu, O.S., Taranger, G.L. Andersson, E., Stefansson, S.O., (Eds.), Proceedings of the 6th International Symposium on the Reproductive Physiology of Fish. John Grieg A/S, Bergen, pp. 396-398.

King, H.R., Pankhurst, N.W. 2003. Ovarian growth and plasma sex steroid and vitellogenin profiles during vitellogenesis in Tasmanian female Atlantic salmon (Salmo salar). Aquaculture 219, 797-813.

King, H.R., Pankhurst, N.W. 2004a. Effect of short-term temperature reduction on ovulation and LHRHa responsiveness in female Atlantic salmon (Salmo salar) maintained at elevated water temperatures. Aquaculture 238, 421-436.

King, H.R., Pankhurst, N.W. 2004b. Effect of maintenance at elevated temperatures on ovulation and luteinizing hormone releasing hormone analogue responsiveness of female Atlantic salmon (Salmo salar) in Tasmania. Aquaculture 233, 583-597.

King, H.R., Pankhurst, N.W., Watts, M., Pankhurst, P.M. 2003. Effect of elevated summer temperatures on gonadal steroid production, vitellogenesis and egg quality in female Atlantic salmon. J. Fish Biol. 63, 153-167.

King, H.R., Pankhurst, N.W., Watts, M. 2007. Reproductive sensitivity to elevated water temperatures in female Atlantic salmon is heightened at certain stages of vitellogenesis. J. Fish Biol. 70, 190-205.

Korsgaard, B., Mommsen, T.P., Saunders, R.L. 1986. The effect of temperature on the vitellogenic response in Atlantic salmon post-smolts (Salmo salar).

Gen.Comp. Endocrinol. 62, 191-201.

Lubzens, E., Young, G., Bobe, J., Cerdá, J. 2010. Oogenesis in teleosts: How fish eggs are formed. Gen. Comp. Endocrinol. 165, 367-389.

Modig, C., Westerlund, L., Olsson, P-E. 2007. Oocyte zona pellucida proteins. In Babin, P.J., Cerdá, J., Lubzens, E. (Eds.), The Fish Oocyte; From Basic Studies to Biotechnical Applications. Springer, Dordrecht, pp. 113-139.

Nocillado, J.N., Levavi-Sivan, B. Carrick, F., Elizur, A. 2007. Temporal expression of G-protein coupled receptor 54 (GPR54), gonadotropin-releasing hormones $(\mathrm{GnRH})$ and dopamine receptor D2 ( $d r d 2)$ in pubertal female grey mullet, Mugil cephalus. Gen. Comp. Endocrinol. 150, 278-287.

Okuzawa, K. 2002. Puberty in teleosts. Fish Physiol. Biochem. 26, 31-41.

Okuzawa, K., Kumakura, N., Gen, K., Yamaguchi, S., Lim, B-S., Kagawa, H. 2003. Effect of high water temperature on brain-pituitary-gonad axis of the red seabream during its spawning season. Fish Physiol. Biochem. 28, 439-440.

Pakkasmaa, S., Peuhkuri, N., Laurila, A., Hirvonen, H., Ranta, E. 2001. Female and male contribution to egg size in salmonids. Evol. Ecol. 15, 143-153.

Pankhurst, N.W. 2008. Gonadal steroids: Functions and patterns of change. In Rocha, M.J., Arukwe, A., Kapoor, B.G. (Eds.), Fish Reproduction. Science Publishers, Enfield, pp. 67-111.

Pankhurst, N.W., Carragher, J.F. 1992. Oocyte maturation and changes in plasma steroid levels in snapper Pagrus (=Chrysophrys) auratus (Sparidae) following treatment with human chorionic gonadotropin. Aquaculture 101, 337-347. 
Pankhurst, N.W., King, H.R. 2010. Temperature and salmonid reproduction: implications for aquaculture. J. Fish Biol. 76, 69-85.

Pankhurst, N.W., Thomas, P.M. 1998. Maintenance at elevated temperature delays the steroidogenic and ovulatory responsiveness of rainbow trout Oncorhynchus mykiss to luteinizing hormone releasing hormone analogue. Aquaculture 166, 163-177.

Pankhurst, N.W., Purser, G.J., Van Der Kraak, G., Thomas, P.M., Forteath, G.N.R. 1996. Effect of holding temperature on ovulation, egg fertility, plasma levels of reproductive hormones and in vitro ovarian steroidogenesis in the rainbow trout Oncorhynchus mykiss. Aquaculture 146, 277-290.

Pankhurst, N.W., Ludke, S.L., King, H.R., Peter, R.E. 2008. The relationship between acute stress, food intake, endocrine status and life history stage in juvenile farmed Atlantic salmon, Salmo salar. Aquaculture 275, 311-318.

Pfaffl, M.W., Horgan, G.W., Dempfle, L. 2002. Relative expression software tool (RESTC) for group-wise comparison and statistical analysis of relative expression results in real-time PCR. Nucleic Acids Res. 30, e36.

Phillips, R., Rix, M. 1988. A Guide to the Freshwater Fish of Britain, Ireland and Europe. Treasure Press, London, 144p.

Prat, F., Sumpter, J.P., Tyler, C.R. 1996. Validation of radioimmunoassays for two salmon gonadotropins (GTH I and GTH II) and their plasma concentrations throughout the reproductive cycle in male and female rainbow trout (Oncorhynchus mykiss). Biol. Reprod. 54, 1375-1382.

Reddin, D.G., Helbig, J., Thomas, A., Whitehouse, B.G., Friedland, K.D. 2000. Survival of Atlantic salmon (Salmo salar L.) related to marine climate. In Mills D. (Ed.), The Ocean Life of Atlantic Salmon. Blackwell Science, Oxford, pp. 88-91.

Schreck, C.B. 2010. Stress and fish reproduction: The roles of allostasis and hormesis. Gen. Comp. Endocrinol. 165, 549-556.

Scott, A.P., Sumpter, J.P. 1983. A comparison of the female reproductive cycles of autumn spawning and winter spawning strains of rainbow trout Salmo gairdneri. Gen. Comp. Endocrinol. 52, 79-85.

Soria, F.N., Strüssman, C.A., Miranda, L.A. 2008. High water temperatures impair the reproductive ability of the pejerrey fish Odontesthes bonariensis: Effects on the hypophyseal-gonadal axis. Physiol. Biochem. Zool. 81, 898-905.

Steinum, T., Kvellestad, A., Rønneberg, L.B., Nilsen, H., Asheim, A., Fjell, K., Nygård,, S.M.R., Olsen, A.B., Dale, A.B. 2008. First cases of amoebic gill disease (AGD) in Norwegian seawater farmed Atlantic salmon, Salmo salar L., and phylogeny of the causative amoeba using 18s cDNA sequences. J. Fish Diseases 31, 205-214.

Sumpter, J.P., Scott, A.P., Baynes, S.M., Witthames, P.R. 1984. Early stages of the reproductive cycle in virgin female rainbow trout (Salmo gairdneri Richardson). Aquaculture 43, 235-242.

Sun, B., Pankhurst, N.W., Watts, M. 2003. Development of an enzyme-linked immunosorbent assay (ELISA) for vitellogenin measurement in greenback flounder Rhombosolea tapirina. Fish Physiol. Biochem. 29, 13-21.

Taranger, G.L., Hansen, T. 1993. Ovulation and egg survival following exposure of Atlantic salmon, Salmo salar L., broodstock to different water temperatures. Aquacult. Fish. Manag. 24, 151-156. 
Taranger, G.L., Carillo, M., Schulz, R.W., Fontaine, P., Zanuy, S., Felip, A., Weltzien, F.A., Dufour, S., Karlsen, Ø., Norberg, B., Andersson, E., Hansen, T. 2010. Control of puberty in farmed fish. Gen. Comp. Endocrinol. 165, 483-515.

Taranger, G.L., Vikingstad, E., Klenke, U., Mayer, I., Stefansson, S.O., Norberg, B., Hansen, T., Zohar, Y., Andersson, E. 2003. Effects of photoperiod, temperature and GnRHa treatment on the reproductive physiology of Atlantic salmon (Salmo salar L.) broodstock. Fish Physiol. Biochem. 28, 403-406.

Thomas, P.M., Pankhurst, N.W., Bremner, H.A. 1999. The effect of stress and exercise on post-mortem biochemistry of Atlantic salmon (Salmo salar) and rainbow trout (Oncorhynchus mykiss). J. Fish Biol. 54, 1177-1196.

Tyler, C.R., Sumpter, J.P., Witthames, P.R. 1990. The dynamics of oocyte growth during vitellogenesis in the rainbow trout (Oncorhynchus mykiss). Biol. Reprod. 43, 202-209.

Tyler, C.R., Santos, E.M., Prat, F. 2000. Unscrambling the egg - cellular, biochemical, molecular and endocrine advances in oogenesis. In Norberg, B., Kjesbu, O.S., Taranger, G.L., Andersson, E., Stefansson, S.O. (Eds.), Proceedings of the $6^{\text {th }}$ International Symposium on the Reproductive Physiology of Fish. John Grieg A/S, Bergen, pp. 273-280.

Vikingstad, E., Andersson, E., Norberg, B., Mayer, I., Klenke, U., Zohar, Y., Stefansson, S.O., Taranger, G.L. 2008. The combined effects of temperature and GnRHa treatment on the final stages of sexual maturation in Atlantic salmon (Salmo salar L.) females. Fish Physiol. Biochem. 34, 289-298.

Watts, M., Pankhurst, N.W., King, H.R. 2004. Maintenance of Atlantic salmon (Salmo salar) at elevated temperature inhibits cytochrome $\mathrm{P}_{450}$ aromatase activity in isolated ovarian follicles. Gen. Comp. Endocrinol. 135, 381-390.

Watts, M., Pankhurst, N.W., Sun, B. 2003. Vitellogenin isolation, purification and antigenic cross reactivity in three teleost species. Comp. Biochem. Physiol. 134B, 467-476.

Welch, D.W., Ishida, Y., Nagasawa, K. 1998a. Thermal limits and ocean migrations of sockeye salmon (Oncorhynchus nerka): long-term consequences of global warming. Can. J. Fish. Aquat. Sci. 55, 937-948.

Welch, D.W., Ishida, Y., Nagasawa, K., Eveson, P. 1998b. Thermal limits on the ocean distribution of steelhead trout (Oncorhynchus mykiss). Nth. Pacific Anadr. Fish Com. Bull. 1, 396-404. 
Table 1

Degenerate PCR primers used for ZPC isolation.

\begin{tabular}{cccc}
\hline $\begin{array}{c}\text { Gene } \\
\text { name }\end{array}$ & $\begin{array}{c}\text { Primer } \\
\text { name }\end{array}$ & Sequence $\left(5^{\prime} \rightarrow 3^{\prime}\right)$ & $\begin{array}{c}\text { Product } \\
\text { size }\end{array}$ \\
\hline \hline & ZPCF1 & ACT CCC TSR TCT ACA YCT TCA & \\
ZPC & & C & 491bp
\end{tabular}

ZPCR1 CTG GAA CCT GAA RGC YTC CA

bp = base pairs, Degenerate base codes: $\mathrm{S}=\mathrm{GC}, \mathrm{R}=\mathrm{AG}, \mathrm{Y}=\mathrm{CT}$ and $\mathrm{K}=\mathrm{GT}$

Table 2.

qPCR primers

\begin{tabular}{|c|c|c|c|c|c|}
\hline $\begin{array}{l}\text { Gene } \\
\text { name }\end{array}$ & $\begin{array}{l}\text { Primer } \\
\text { name }\end{array}$ & Sequence $\left(5^{\prime} \rightarrow 3^{\prime}\right)$ & $\begin{array}{c}\text { Prod. } \\
\text { size }\end{array}$ & $\mathrm{E}^{*}$ & $\begin{array}{c}\text { Source } \\
\text { sequence }\end{array}$ \\
\hline \multirow{2}{*}{ Vtg } & VtgF4 & AAC TTT GCC CCT GAA TTT GC & \multirow{2}{*}{ 95bp } & \multirow{2}{*}{0.984} & \multirow{2}{*}{ DQ834857 } \\
\hline & VtgR4 & GCT CTA GCC AGA CCC TCC GC & & & \\
\hline \multirow{2}{*}{$\mathrm{ZPB}$} & ZPBF1 & GTTT CCA GGG ATG CCA CTC T & \multirow{2}{*}{ 113bp } & \multirow{2}{*}{0.937} & \multirow{2}{*}{$\begin{array}{l}\text { AJ000664, } \\
\text { AJ000665 }\end{array}$} \\
\hline & ZPBR1 & TGG TAG ATG GCA AAG GCA GA & & & \\
\hline \multirow{2}{*}{ ZPC } & ZPCF5 & GTC CCC CTG CGT ATC TTT GT & \multirow{2}{*}{ 121bp } & \multirow{2}{*}{0.969} & \multirow{2}{*}{ GU075906 } \\
\hline & ZPCR4 & AAC CTG TCA CTT TGG CAT CG & & & \\
\hline \multirow{2}{*}{ HPRT1 } & HPRT1F1 & GAT GAT GAG CAG GGA TATGAC & \multirow{2}{*}{ 165bp } & \multirow{2}{*}{0.963} & \multirow{2}{*}{ ВT043501 } \\
\hline & HPRT1R1 & GCA GAG AGC CAC GAT ATG G & & & \\
\hline \multirow{2}{*}{ TBP } & TBPF1 & TCC CCA ACC TGT GAC GAA CA & \multirow{2}{*}{ 117bp } & \multirow{2}{*}{0.981} & \multirow{2}{*}{ ВТ059217 } \\
\hline & TBPR1 & GTC TGT CCT GAG CCC CCT GA & & & \\
\hline \multirow{2}{*}{ EF1 $\alpha$} & $\mathrm{EF} 1 \alpha \mathrm{F} 2$ & GCA CCA CGA GAC CCT GGA AT & \multirow{2}{*}{ 94bp } & \multirow{2}{*}{0.969} & \multirow{2}{*}{ AF321836 } \\
\hline & $\mathrm{EF} 1 \alpha \mathrm{R} 2$ & CAC GTT GCC ACG ACG GAT AT & & & \\
\hline \multirow{2}{*}{$\begin{array}{c}\beta- \\
\text { tubulin }\end{array}$} & $\beta \mathrm{TubF} 1$ & CCG TGC TTG TCG ACT TGG AG & \multirow{2}{*}{ 144bp } & \multirow{2}{*}{0.975} & \multirow{2}{*}{ DQ367888 } \\
\hline & $\beta$ TubR2 & CAG CGC CCT CTG TGT AGT GG & & & \\
\hline
\end{tabular}

$\mathrm{E}=$ efficiency, $\mathrm{bp}=$ base pairs, $\mathrm{TBC}=$ to be confirmed 
Table 3.

Proportion of fish with atretic follicles present in histological sections of ovary.

\begin{tabular}{c|cccccc}
\hline & \multicolumn{7}{|c}{ Sample } \\
\hline Group $^{1}$ & 1 & 2 & 3 & 4 & 5 & 6 \\
1 & 0 & 0 & 0 & 0 & $2 / 7$ & $2 / 7$ \\
2 & $6 / 7^{2}$ & $6 / 7^{2}$ & $4 / 7^{2}$ & $5 / 7^{2}$ & $2 / 7$ & $2 / 7$ \\
3 & - & - & - & $2 / 7$ & $3 / 7$ & $5 / 7$ \\
\hline 4 & - & - & - & $2 / 7$ & $5 / 7$ & $5 / 7$ \\
\hline
\end{tabular}

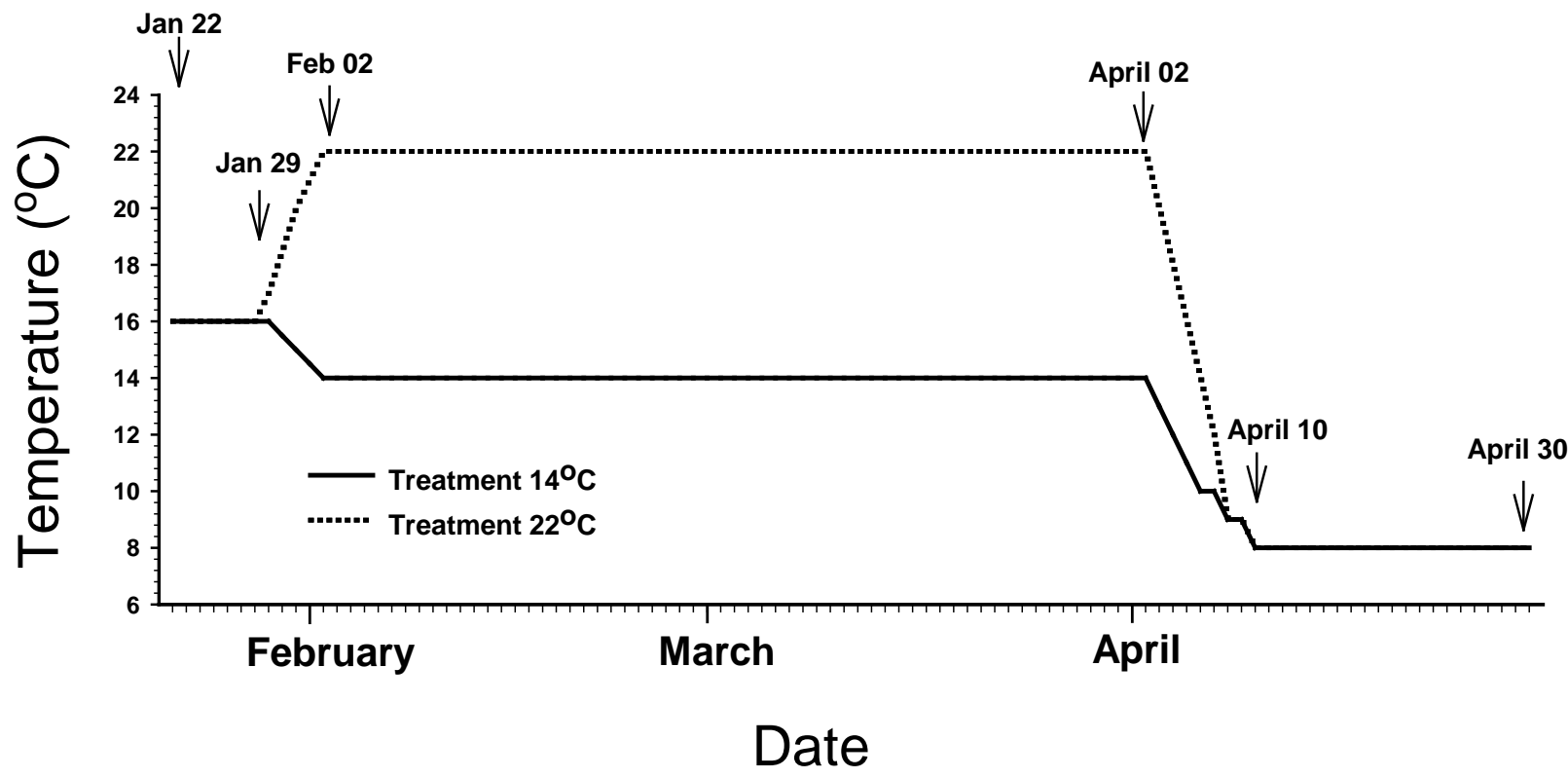

Fig. 1. Thermal treatment regimes for Atlantic salmon maiden and repeat spawners in $14{ }^{\circ} \mathrm{C}$ and $22{ }^{\circ} \mathrm{C}$ treatments. 

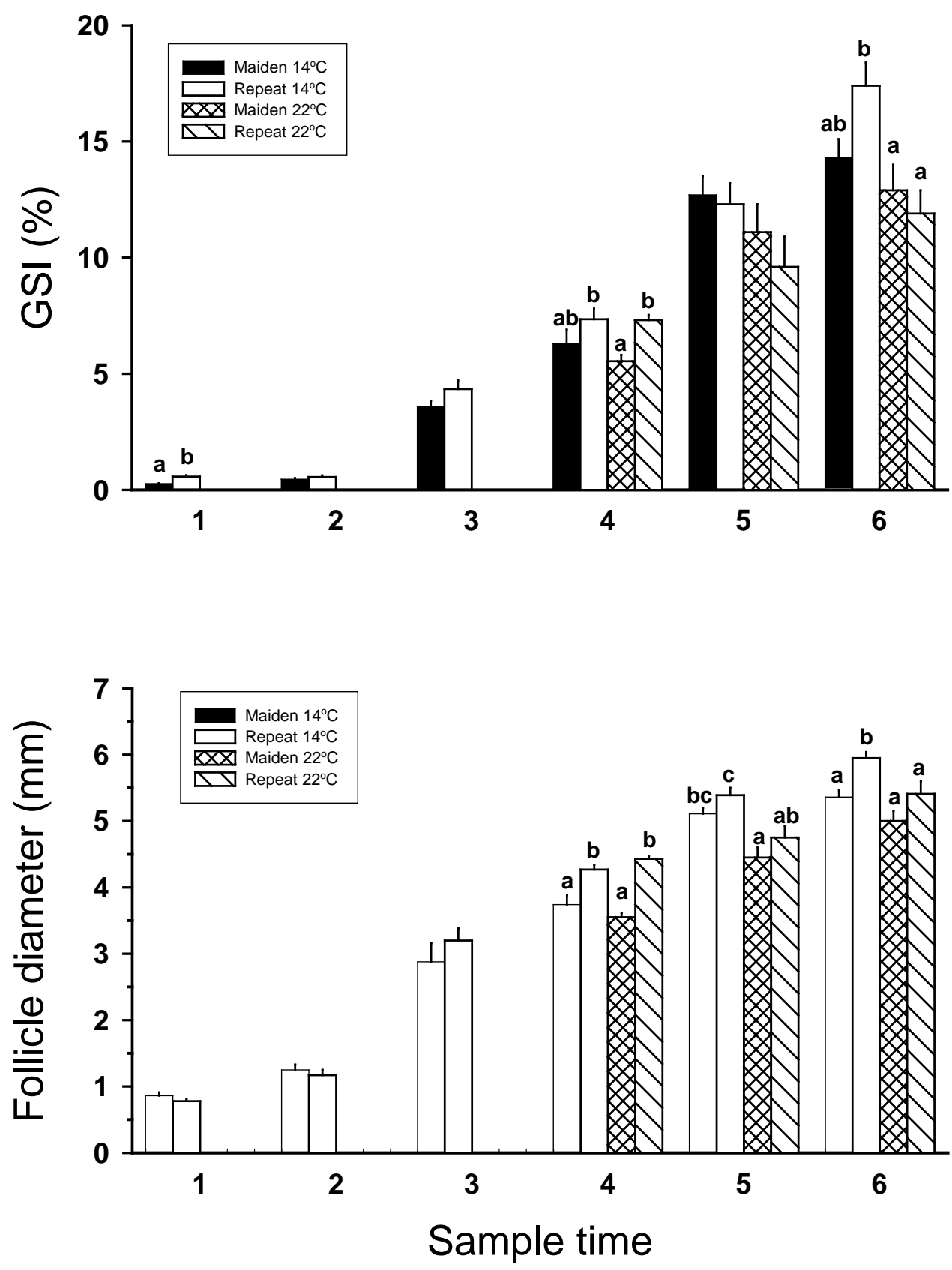

Figure 2. Gonadosomatic index and follicle diameters (mean + SE [n = 7]) of; maiden spawners held at $14{ }^{\circ} \mathrm{C}$ (filled bars); repeat spawners held at $14{ }^{\circ} \mathrm{C}$ (open bars) maidens at $22{ }^{\circ} \mathrm{C}$ (cross-hatched bars), and repeats at $22{ }^{\circ} \mathrm{C}$ (hatched bars) during autumn (sample times are given in Materials and Methods). Different superscripts within sample times denote significant differences $(\mathrm{P}<0.05)$. 


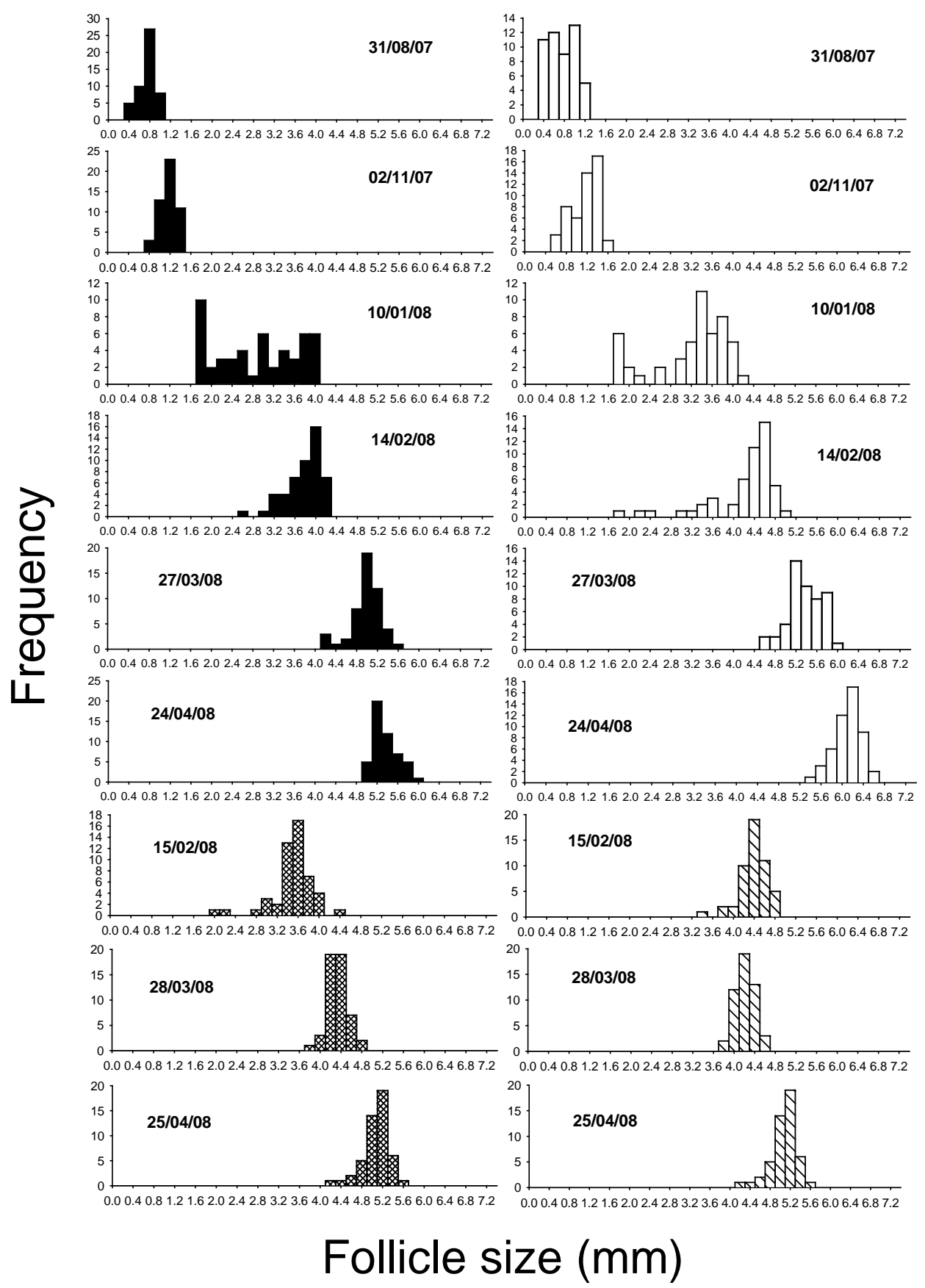

Fig. 3. Follicle size distribution for individual maiden and repeat spawners exposed to A) $14{ }^{\circ} \mathrm{C}$ or B) $22{ }^{\circ} \mathrm{C}$. Fish shown have mean follicle diameters that approximate the group mean for that sample time. Other details as for Fig. 2. 

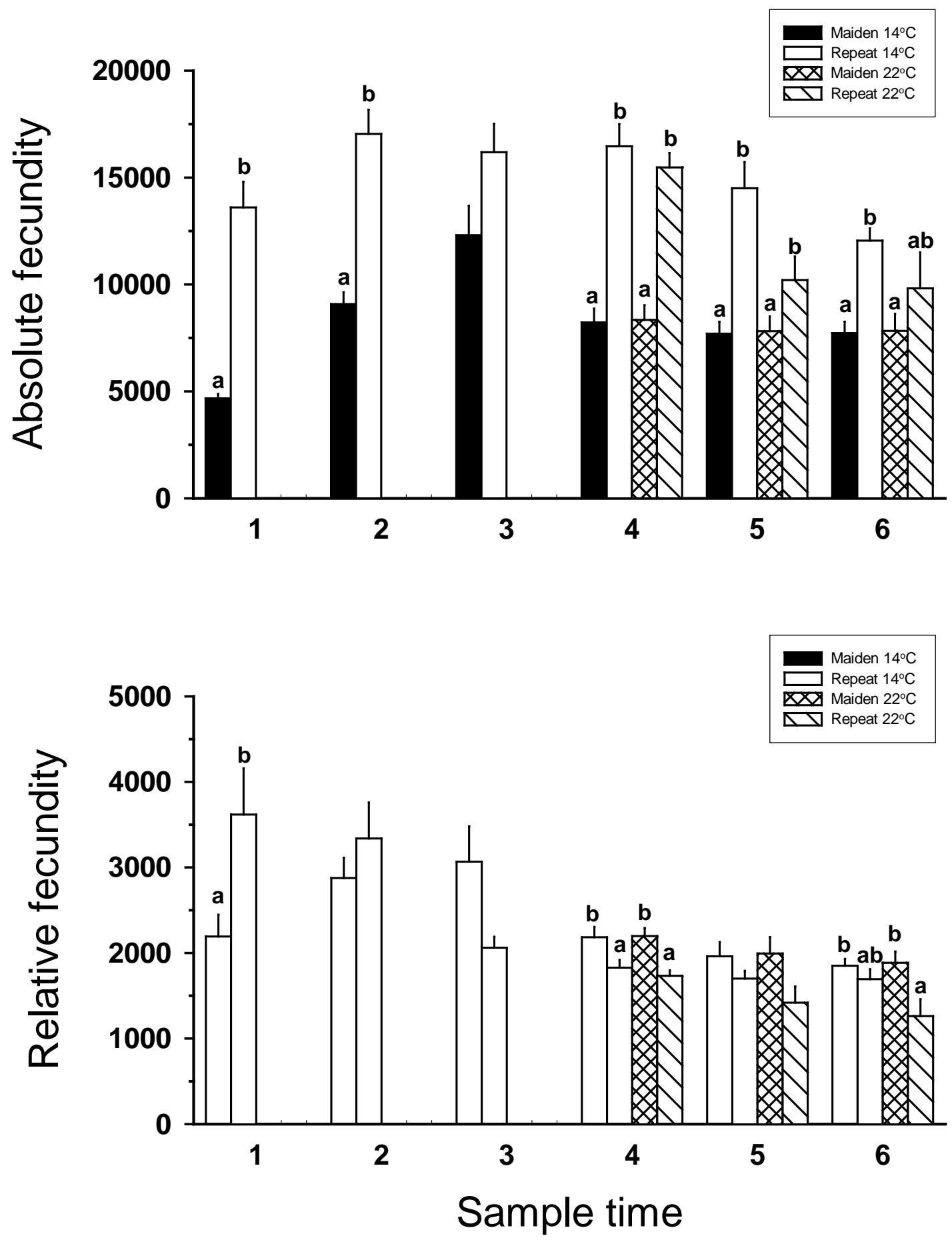

Fig. 4. Absolute and relative fecundity of maiden and repeat spawners exposed to 14 ${ }^{\circ} \mathrm{C}$ or $22{ }^{\circ} \mathrm{C}$ during autumn. Other details as for Fig. 2. 


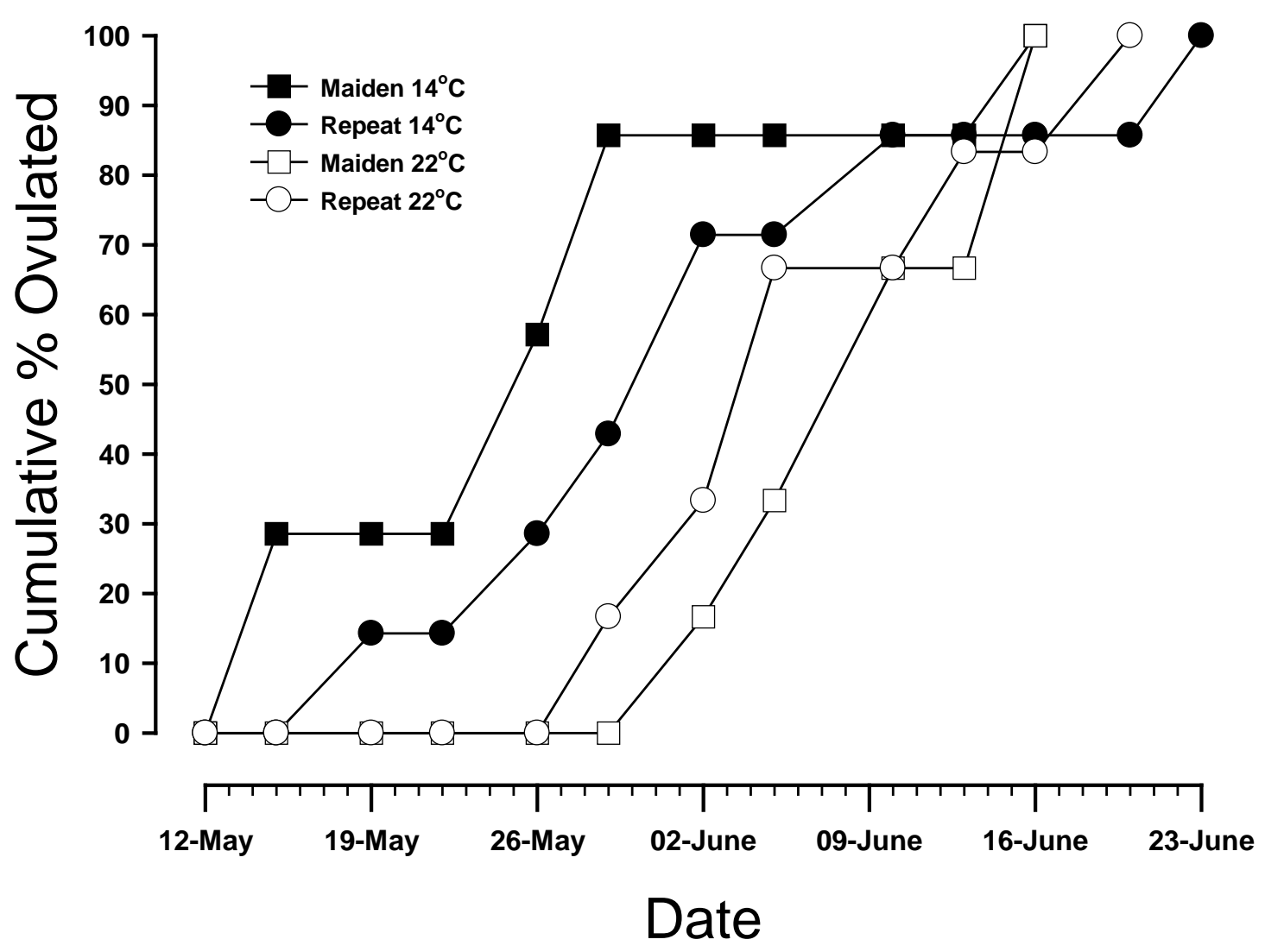

Fig. 5. Cumulative ovulation in maidens at $14{ }^{\circ} \mathrm{C}$ (filled squares); repeats at $14{ }^{\circ} \mathrm{C}$ (filled circles); maidens at $22{ }^{\circ} \mathrm{C}$ (open squares), and repeats at $22{ }^{\circ} \mathrm{C}$ (open circles). 

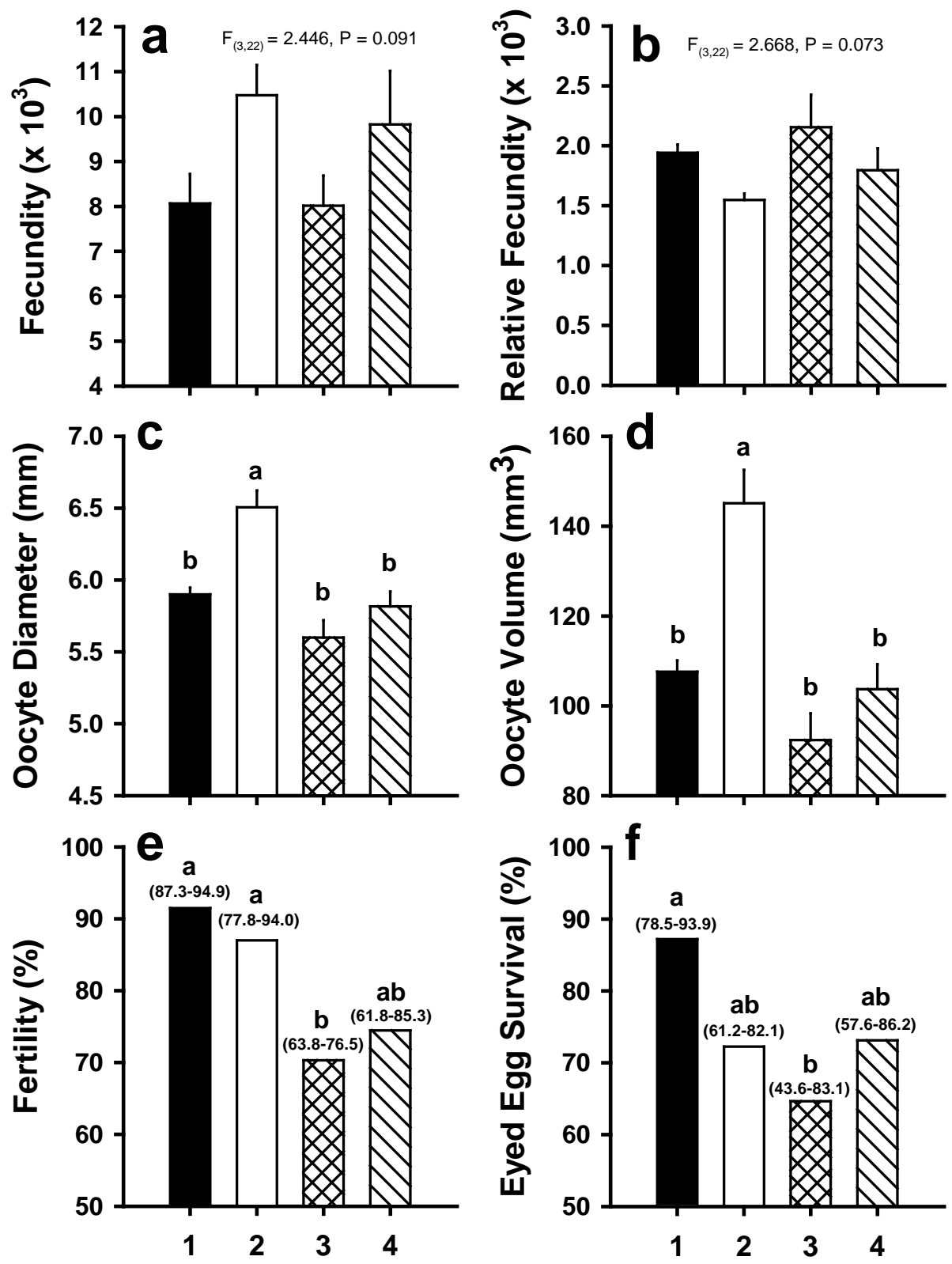

Treatment Group

Fig. 6. Post-ovulatory fecundity, fertility and survival to eyed stage from maidens and repeat spawners exposed to $14{ }^{\circ} \mathrm{C}$ or $22{ }^{\circ} \mathrm{C}$ during autumn. Other details as for Fig. 2. 

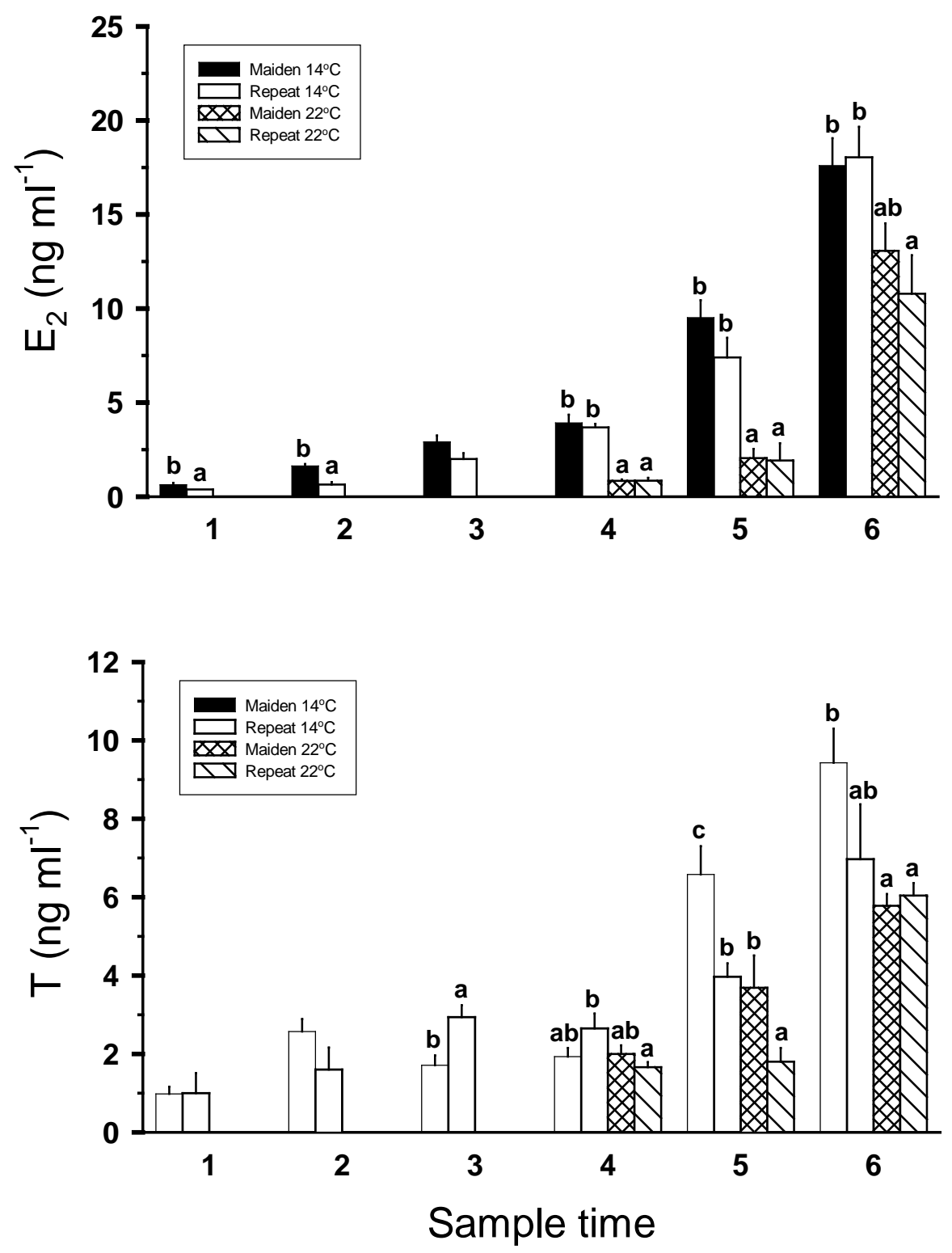

Fig. 7. Plasma levels of testosterone $(\mathrm{T})$ and oestradiol $\left(\mathrm{E}_{2}\right)$ among maiden and repeat spawners exposed to $14{ }^{\circ} \mathrm{C}$ or $22{ }^{\circ} \mathrm{C}$ during autumn. Other details as for Fig. 2 . 

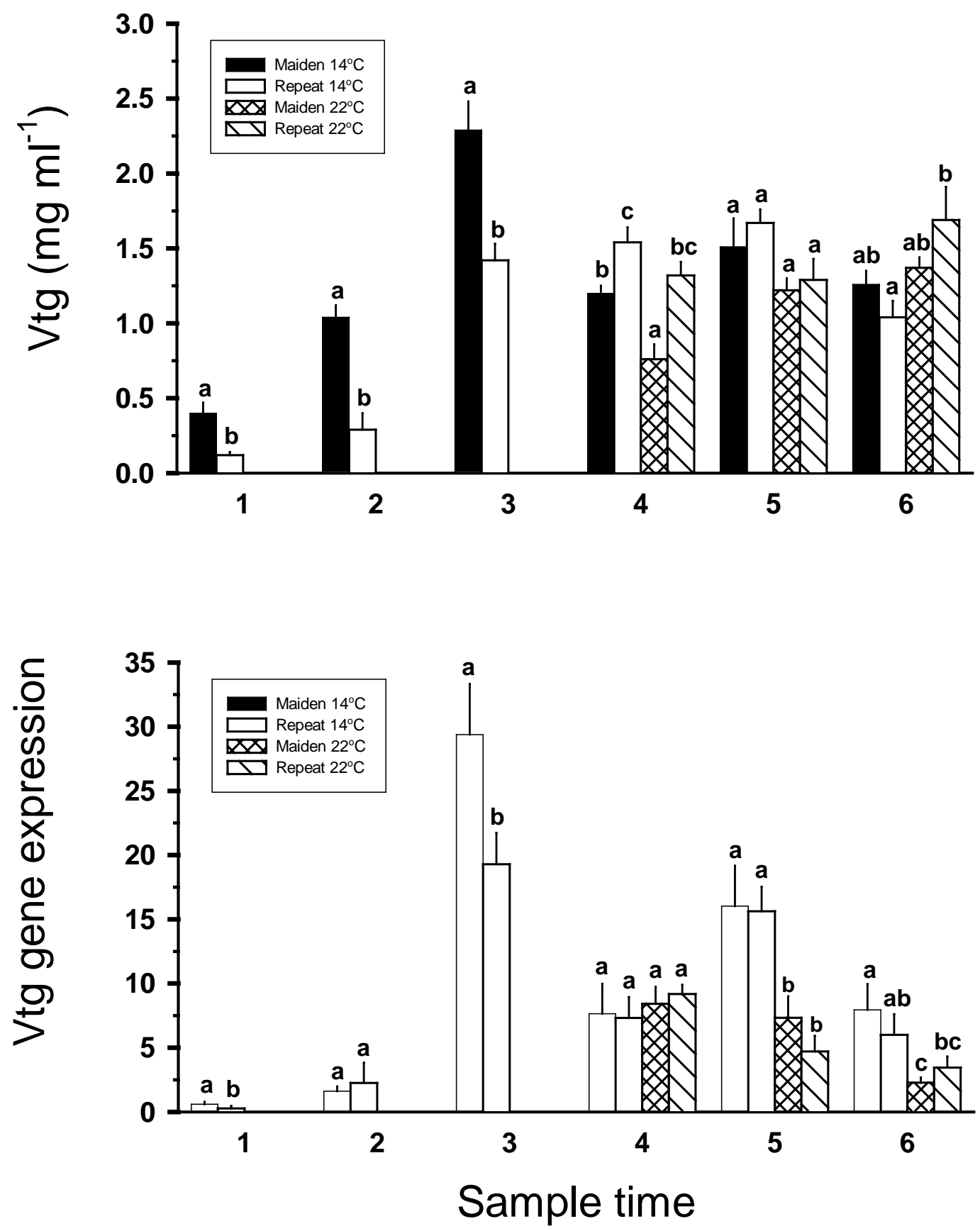

Fig. 8. Plasma levels of Vitellogenin (Vtg) and relative Vtg gene expression among maiden and repeat spawners exposed to $14{ }^{\circ} \mathrm{C}$ or $22{ }^{\circ} \mathrm{C}$ during autumn. Other details as for Fig. 2. 

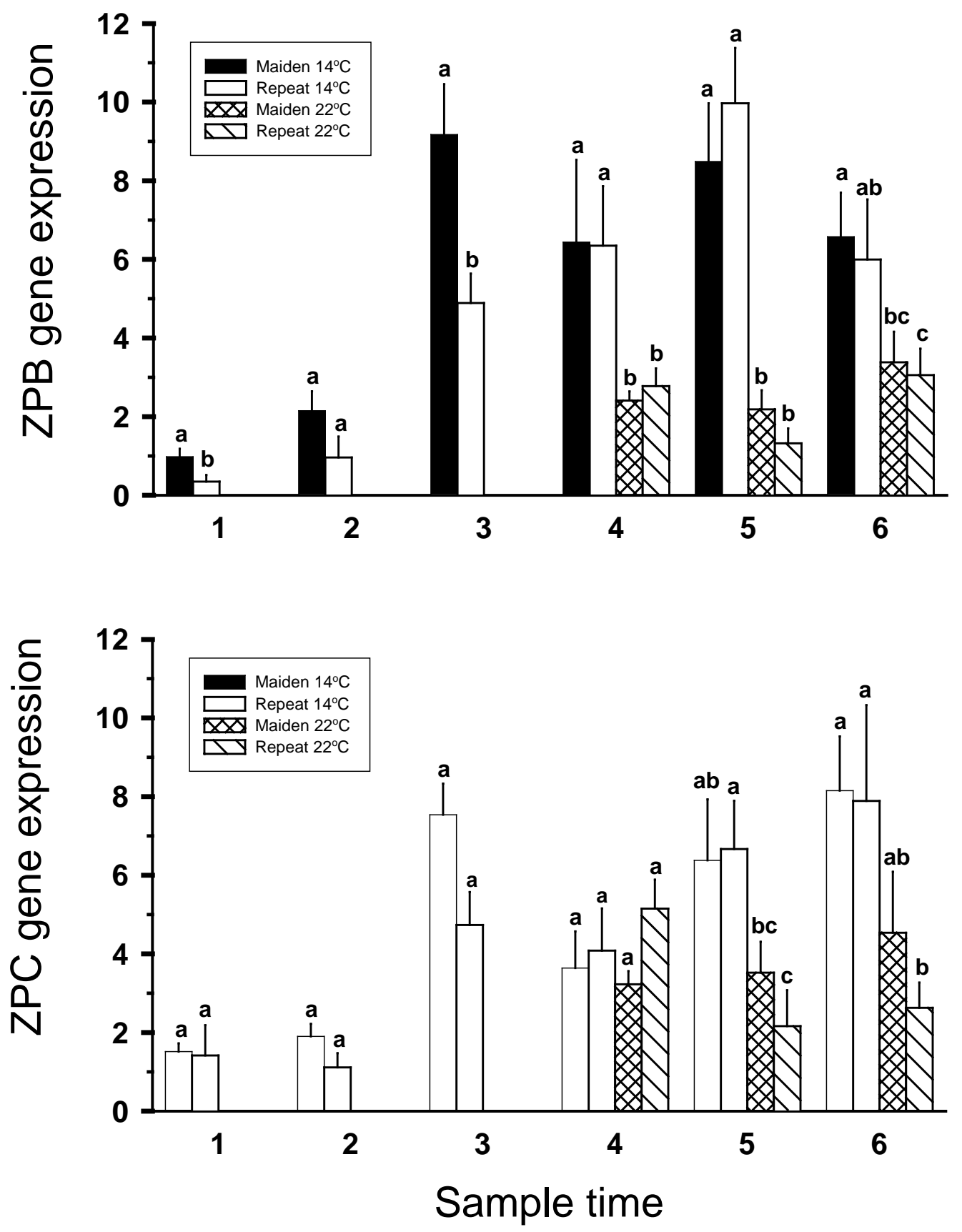

Fig. 9. Relative zona pellucida $\mathrm{B}(\mathrm{ZPB})$ and $\mathrm{C}$ (ZPC) gene expression among maiden and repeat spawners exposed to $14{ }^{\circ} \mathrm{C}$ or $22{ }^{\circ} \mathrm{C}$ during autumn. Other details as for Fig. 2. 